WSRC-RP-96-00832, Rev. 1, Final

\title{
Record of Decision Remedial Alternative Selection for the Gunsite 720 Rubble Pit Operable Unit: Final Action (631-16G)
}

by

E. Palmer

Westinghouse Savannah River Company

Savannah River Site

Aiken, South Carolina 29808

DOE Contract No. DE-AC09-96SR18500

This paper was prepared in connection with work done under the above contract number with the U.S.

Department of Energy. By acceptance of this paper, the publisher and/or recipient acknowledges the U.S. Government's right to retain a nonexclusive, royalty-free license in and to any copyright covering this paper, along with the right to reproduce and to authorize others to reproduce all or part of the copyrighted paper.

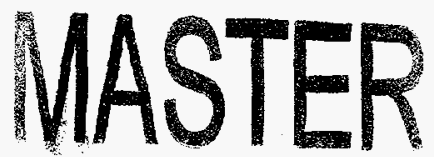

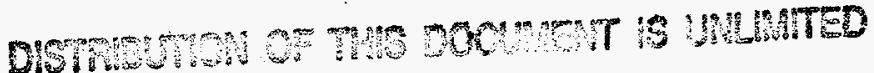

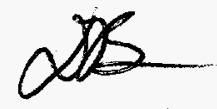




\section{DISCLAIMER}

This report was prepared as an account of work sponsored by an agency of the United States Government. Neither the United States Government nor any agency thereof, nor any of their employees, makes any warranty, express or implied, or assumes any legal liability or responsibility for the accuracy, completeness, or usefulness of any information, apparatus, product, or process disclosed, or represents that its use would not infringe privately owned rights. Reference herein to any specific commercial product, process, or service by trade name, trademark, manufacturer, or otherwise does not necessarily constitute or imply its endorsement, recommendation, or favoring by the United States Government or any agency thereof. The views and opinions of authors expressed herein do not necessarily state or reflect those of the United States Government or any agency thereof.

This report has been reproduced directly from the best available copy.

Available to DOE and DOE contractors from the Office of Scientific and Technical Information, P.O. Box 62, Oak Ridge, TN 37831; prices available from (615) 576-8401.

Available to the public from the National Technical Information Service, U.S. Department of Commerce; 5285 Port Royal Road, Springfield, VA 22161. 


\section{DISCLAIMER}

Portions of this document may be illegible electronic image products. Images are produced from the best available original document. 


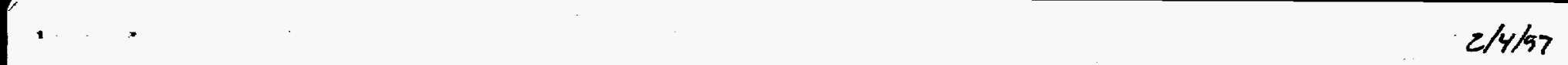

\section{United States Department of Energy Savannah River Site}

Record of Decision

Remedial Alternative Selection for the Gunsite 720 Rubble Pit (631-16G) Operable Unit: Final Action(U)

WSRC-RP-96-00832

Revision 1

January 1997

Prepared by:

Westinghouse Savannah River Company

Savannah River Site

Aiken, South Carolina 29808

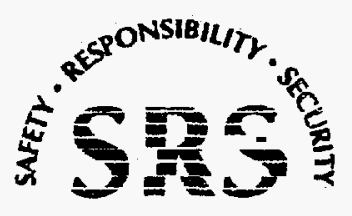

SAVANNAH RIVERSIIE

Prepared for the U.S. Department of Energy Under Contract No. DE-AC09-96SR18500 


\title{
RECORD OF' DECISION REMEDIAL ALTERNATIVE SELECTION(U)
}

The Gunsite 720 Rubble Pit (631-16G)

Operable Unit: Final Action

\author{
WSRC-RP-96-00832 \\ Revision 1 \\ January 1997
}

Savannah River Site

Aiken, South Carolina

\author{
Prepared by: \\ Westinghouse Savannah River Company \\ for the \\ U.S. Department of Energy undar Contract DE.AC09-96SR1 8500 \\ Savannah River Operations Office \\ Aiken, South Carolina
}




\section{DECLARATION FOR THE RECORD OF DECISION}

\section{Unit Name and Location}

Gunsite 720 Rubble Pit Unit

(SRS Building 631-16G)

Savannah River Site

Aiken, South Carolina

The Gunsite 720 Rubble Pit Unit (631- 16G) is listed as a Resource Conservation and Recovery Act (RCRA) 3004(u) Solid Waste Management Unit/Comprehensive Environmental Response, Compensation, and Liability Act (CERCLA) Unit in Appendix C of the Federal Facility Agreement (FFA) for the Savannah River Site (SRS).

\section{Statement of Basis and Purpose}

This decision document presents the selected remedial action for the Gunsite 720 Rubble Pit Unit located at the Savannah River Site near Aiken, South Carolina. The selected action was developed in accordance with CERCLA, as amended, and to the extent practicable, the National Oil and Hazardous Substances Pollution Contingency Plan (NCP). The selected remedy satisfies both CERCLA and RCRA 3004(u) requirements. This decision is based on the Administrative Record File for this specific RCRA/CERCLA Unit.

\section{Description of the Selected Remedy}

The results of the Resource Conservation and Recovery Act Facility Investigation/ Comprehensive Environmental Response, Compensation, and Liability Act Remedial Investigation, indicate that the Gunsite 720 Rubble Pit Unit poses no risk to human health or the environment. Therefore, no action is needed at the Gunsite 720 Rubble Pit Unit. This is the final RCRAVCERCLA action for the Gunsite 720 Rubble Pit Unit. The South Carolina Department of Health and Environmental Control has modified the SRS RCRA permit to incorporate the selected remedy.

\section{Declaration Statement}

Based on the results of the remedial investigation, no action is necessary at the Gunsite 720 Rubble Pit Unit to ensure the protection of human heakh and the environment. Since the Gunsite 720 Rubble Pit Unit poses no threat to human health or the environment, and no action is needed, the CERCLA Section 121 requirements are not applicable. This action is protective of human health and the environment and is meant to be a permanent solution, final action, for the Gunsite 720 Rubble Pit Unit. No five-year remedy review is needed or will be performed. 
003842

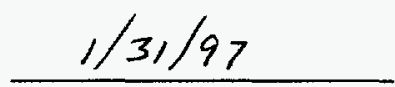

Date
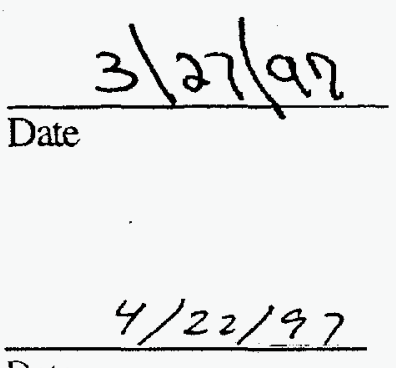

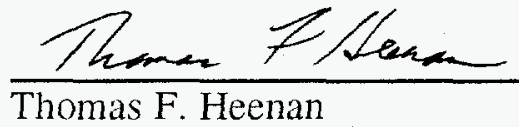

Assistant Manager for Environmental Quality

U.S Department of Energy, Sa annah River Operations Office

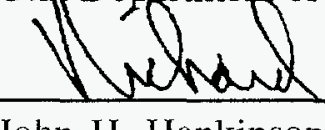

John H. Hankinson, Jr.

Regional Administrator

U.S. Environmental Protection Agency, Region IV
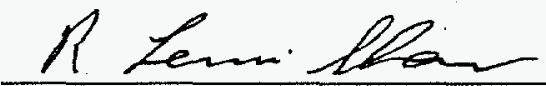

R. Lewis Shaw

Deputy Commissioner

Environmental Quality Control

South Carolina Department of Health and Environmental Control 


\title{
DECISION SUMMARY \\ REMEDIAL ALTERNATIVE SELECTION (U)
}

The Gunsite 720 Rubble Pit (631-16G)

Operable Unit: Final Action

\author{
WSRC-RP-96-00832 \\ Revision 1 \\ January 1997
}

Savannah River Site

Aiken, South Carolina

Prepared by:

Westinghouse Savannah River Company

for the

U.S. Department of Energy under Contract DE-AC09-96SR1 8500

Savannah River Operations Office

Aiken, South Carolina 


\section{Table of Contents}

\section{SECTION}

1. Site and Operable Unit Names, Locations, and Descriptions. . . . . . . - 1

II. Operable Unit History and Compliance History ---

III. Highlights of Community Participation -..." ................. 5

IV. Scope and Role of Operable Unit within the Site Strategy --6

V. Summary of Operable Unit Characteristics - -

VI. Summary of Operable Unit Risks $\ldots \ldots \ldots$

VII. Description of the No Action Alternative -...- 8

VIII. References $\ldots \ldots \ldots \ldots \ldots \ldots \ldots \ldots \ldots \ldots \ldots \ldots \ldots \ldots \ldots \ldots, \ldots \ldots$

\section{List of Figures}

1. Location of the Gunsite 720 Rubble Pit Unit in Relation to Major SRS Facilities -

2. Layout of the Gunsite 720 Rubble Pit Unit Showing Sample Locations and Location and Concentration of Metals which Exceed the Unit-Specific Background Level 


\section{Section L Site and Operable Unit Name, Location, and Description}

\section{Introduction}

The Savannah River Site (SRS) occupies approximately 803 square kilometers (310 square miles) of land adjacent to the Savannah River, principally in Aiken and Barnwell Counties of South Carolina. SRS is a secured U.S. government facility with no permanent residents. SRS is located approximately 40 kilometers (25 miles) southeast of Augusta, GA and 32 kilometers (20 miles) south of Aiken, $\mathrm{SC}$. Figure 1 shows the location of the Gunsite 720 Rubble Pit Urit in relation to other facilities at SR S.

SRS is owned by the Department of Energy (DOE). Management and operating services are provided by Westinghouse Savannah River Company (WSRC). SRS has historically produced tritium, plutonium, and other special nuclear materials for national defense. SRS has also provided nuclear materials for the space program and for medical, industrial, and research efforts. Chemical and radioactive $w$ astes are byproducts of nuclear malerial production processes.

The Federal Facility Agreement (FFA, 1993 ) for SRS lists the Gunsite 720 Rubble Pit Unit (63 1- 16G) as a RCRA/CERCLA Unit that required further evaluation. An investigation/assessment process that integrates and combines the RCRA Facility Investigation (RFI) with the CERCLA Remedial Investigation (RI $j$ to determine the actual or potential impaci to hum an health and the envirorment was performed.

The Gunsite 720 Rubolc Pit Unit is located within SRS and is approximately 305 meters (1000 feet) west of South Carolina Highway 125, 168 melers (550 feet) north of SRS Road A-2, and
2.5 kilometers $(1.5$ miles $)$ from the nearest SRS boundary (see Figure 1).

The topography of the area is relatively flat with an elevation of about 95.7 meters (150 feet) above mean sea level. The unit consists of an open area covered with natural shrub growth and surrounded by native pine trees. The unit encompasses an area of approximately 2,250 square meters (25,000 square feet). Two concrete slabs and an old well are located on the east side of the unit (see Figure 2). Surface drainage in the area is to Upper Three Runs Creek, approximately 1,200 meters (4000 feet) south of the unit. The water table in the area is approximately 10 feet below ground surface.

\section{Section II. Operable Unit History and Compliance History}

\section{Operable Unit History}

During the period from 1955 to 1960 , to defend SRS in the event of an air attack, the U.S. Army established onsite anti-aircraft artillery gun emplacements at several locations near the perimeter of SRS. The Gunsite 720 was one of those emplacements. There is no documentation or record of any hazardous substance management or disposal at this unit. There is no evidence that any recent disposal activity has occurred. Also, there is no evidence of any burning or excavation at this waste unit.

In the early to mid 1980 s, while work was being performed in the area, nine (9) empty, partially buried drums, labeled "duPont Freon 11", were found at the gunsite. The drums were excavated in July 1987, and placed on a pallet at the gunsite. The area around the drums was screened during excavation and the liquid (rainwater) that collected in the excavated 


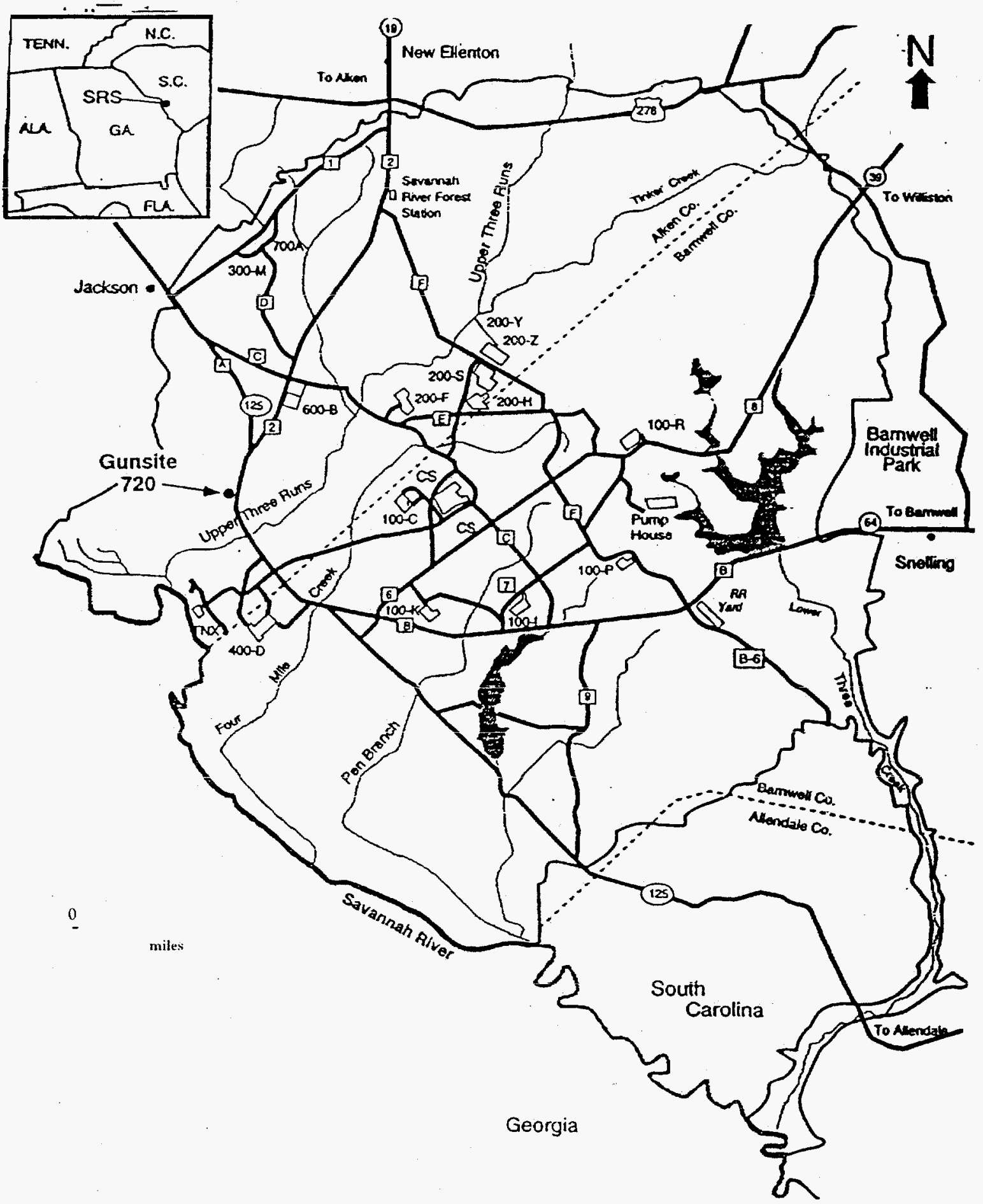

Figure 1. Location of the Gunsite 720 Rubble Pit Unit in Relation to Major SRS Facilities 


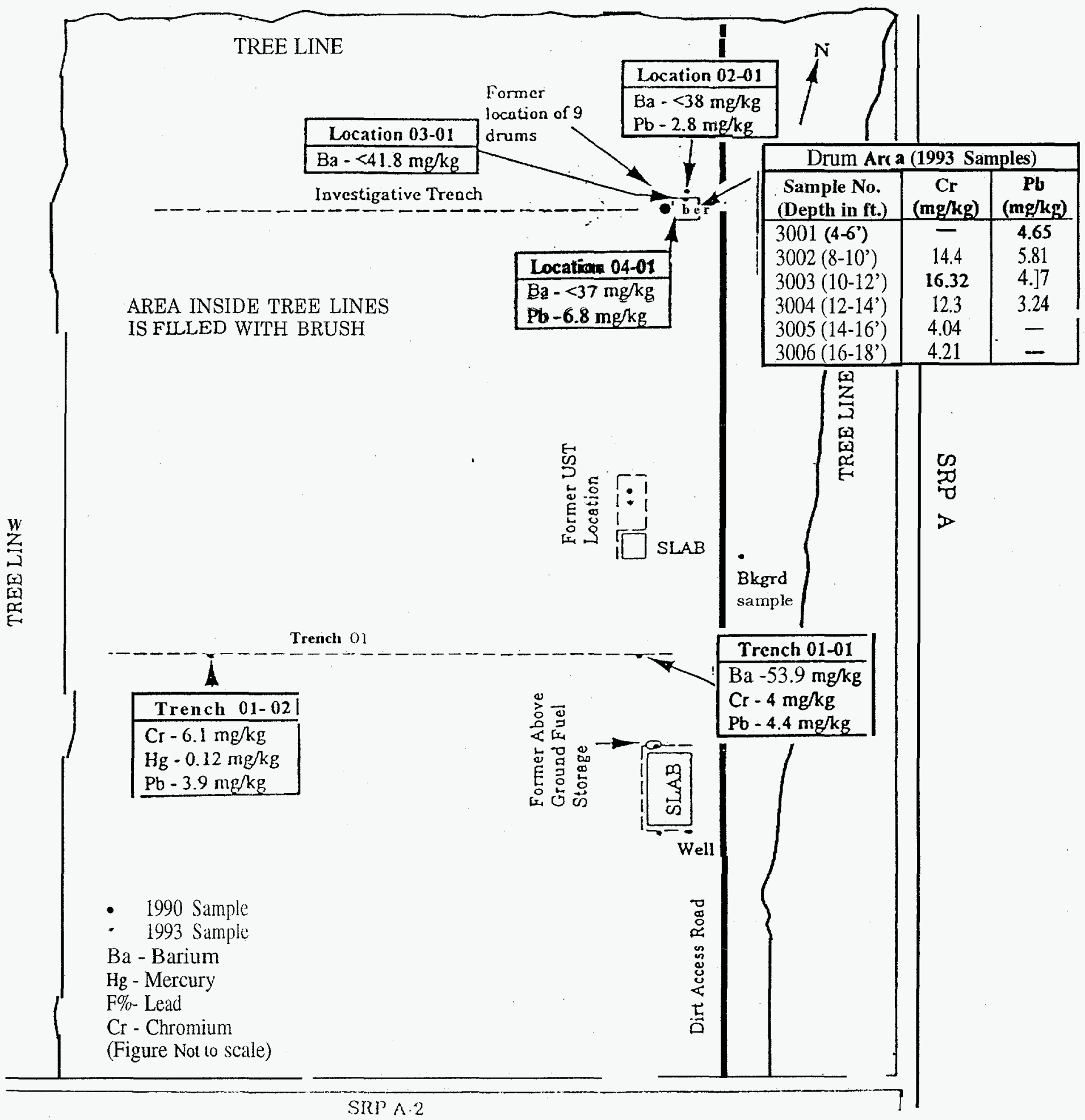

Figure 2. Layout of the Gunsite 720 Rubble Pit Unit Showing Sample Locations and Location and Concentration of Metals which Exceed the Unit-Specific Background Level 
drums was-sampled prior to disposal. No evidence of hazardous substances was found. In October 1989, the drums were removed from the unit. A review of SRS plans and maps: indicated that an underground fuel storage tank was at the gunsite. An above-ground tank was also noted on the maps. However, there is no physical evidence that the tanks still exists at this unit. No contamination, other than household trash (bottles, wrappers, etc.), was noted in the area. Currently, the unit consists of two concrete slabs and an old well.

\section{Compliance History}

At SRS, certain waste materials are managed in accordance with the requirements of the Resource Conservation and Recovery Act (RCRA). To comply with the requirements of RCRA, certain SRS activities have required treatment, storage, or disposal, closure or postclosure RCRA permits.

Non-regulated units, called solid waste management units (SWMU), include any activity where hazardous constituents may remain uncontrolled and may potentially release to the environment. Investigation and potential corrective action for these SWMU(s) are mandated under RCRA 3004(U).

In 1995, SRS received a hazardous waste permit from the South Carolina Department of Health and Environmental Control (SCDHEC), which includes corrective action requirements. Specifically, Part V of the permit mandates that SRS establish and implement a RCRA Facility Investigation (RFI) program to fulfill the requirements specified in Section 3004(u).

Hazardous substances, as defined by CERCLA, are also present in the environment at SRS. On December 21, 1989, SRS was placed on the National Priorities List (NPL). A site placed on the
NPL comes under the requirements of CERCLA. In accordance with Section 120 of CERCLA, DOE has entered into an FFA with EPA and SCDHEC to coordinate cleanup activities at SRS into one comprehensive strategy that fulfills RCRA Section 3004(u) and CERCLA assessment, investigation, and response action requirements.

The remedial investigation for the Gunsite 720 Rubble Pit Unit was conducted from March 1988 to early 1993. The results of the RFI/RI Report completed in 1996 (WSRC, 1996a) indicate that the Gunsite 720 Rubble Pit Unit poses no current or future risk to human health or the environment. Therefore, no action is warranted.

According to EPA guidance, if there is no current or potential threat to human health and the environment and no action is warranted, the CERCLA 121 requirements are not triggered. This means that there is no need to evaluate other alternatives.

To fulfill the public participation requirements of CERCLA, RCRA, and the South Carolina Hazardous Waste Management Regulations (SCHWMR), a Statement of Basis/Proposed Plan (WSRC, 1996b) presenting the no action alternative and the rational for selecting the alternative was prepared and submitted for public comments. The public was provided an opportunity to participate in the remedy selection process and was strongly encouraged to submit comments (see Section III). Following the public comment period, all the comments submitted were reviewed and considered. DOE, in consultation with EPA-Region IV and SCDHEC, selected the final action for the Gunsite 720 Rubble Pit Unit. Final selection of the remedial alternative satisfies FFA requirements. SCDHEC has modified the SRS RCRA permit to incorporate the selected remedy. 


\section{Section III. "Highlights of Community Participation}

Public participation requirements are listed in CERCLA Sections 113 and 117. These requirements include the establishment of an Administrative Record File that documents the selection of remedial alternatives and allows for review and comments by the public regarding those alternatives. The Administrative Record File must be established "at or near the facility at issue". The SRS Public Involvement Plan (DOE, 1994) is designed to facilitate public involvement in- the decision-making process for permitting, closure, and the selection of remedial alternatives. Section 117 (a) of CERCT.A requires publication of a notice of any proposed remedial action and provides the public an opportunity to participate in the selection of a remedial action. The Statement of Basis/Proposed Plan for the Gunsite 720 Rubble Pit Unit, which is part of the Administrative Record File, highlights the aspects of the investigation and identifies the preferred action for addressing the Gunsite 720 Rubble Pit Unit.

RC.R.A provides oppormmiles for the pululic to comment on draftreimit modifications. Public participation requirements are also listed in SCHWMR R.61-79. 124 and require publication of the draft permit modifications. SCHWMR R.61-79.124 requires a brief description and response to all significant comments be made available to the public as a part of the Administrative Record. The preferred alternative proposed in the Statcmert of Basis/Proposed Plan was also proposed as in draft permit modification under RCR A. Therefore, any $\mathrm{com} \mathrm{m}$ e $\mathrm{ts}$ received on the Statement of Basis/Proposed Plan were also applicable to the draft RCRA permit modification, proposing the same remedy for the Gunsite 720 Rubble Pit Unit.
The Administrative Record File, which contains the Statement of Basis/Proposed Plan and all the documents (unabridged) listed in the reference section of this document, is available at the EPA Office and at the following locations:

\section{U.S. Department of Energy}

Public Reading Room

Gregg-Graniteville Library

University of South Carolina-Aiken

171 University Parkway

Aiken, SC 29801

(803) 641-3465

Thomas Cooper Library

Government Documents Department

University of South Carolina

Columbia, SC 29208

(803) $777-4866$

Similar information is available through the repositories listed below:

Reese Library

Augusta State University

2500 Walton Way

Augusta, GA 30910

(706) $737-1744$

Asa H Gordon Libiary

Savannah State University

Tompkins Road

Savannah, GA 31404

(912) 356-2183

The public was notified of a public comment period by mailing the SRS Environmental Bulletin, a newsletter sent to approximately 3500 citizens in South Carolina and Georgia, and through the Aiken Standard, the Allendale Citizen Leader, the Barnwell People-Sentinel, the State, a $\mathrm{n}$ d the Augusta Chronicle newspapers, The public comment period was also announced on local radio stations. The 45-day public comment period began o n September 17, 1996 and ended on October 31,1996 . No public comments were received, 


\section{Section IV. Scope and Role of Operable Unit within the Site Strategy}

The overall strategy for addressing the Gunsite 720 Rubble Pit Operable Unit was to: (1) determine if there had been a release of hazardous substances; (2) determine the nature and extent of any contamination; (3) perform a baseline risk assessment; and (4) evaluate the need for remedial action to address any potential risks to human health and the environment.

The investigation and risk assessment have been completed for the Gunsite 720 Rubble Pit Unit. Since the results of the investigation indicate that the unit poses no' risk to human health or the environment, no action was recommended.

The field investigations and soil sampling conducted during 1990 and 1993 also indicate that there are no hazardous substances at the Gunsite 720 Rubble Pit Unit that would impact the groundwater.

The Gunsite 720 Rubble Pit Unit is an operable unit located within the Upper Three Runs Creek watershed. All the source control and groundwater operable units located within this watershed will be evaluated to determine their impacts, if any, to the associated streams and wetlands.

SRS will manage all source control units to prevent impact to the watershed. Upon disposition of all source control and groundwater operable units within this watershed, a final comprehensive ROD for the Upper Three Runs Creek watershed will be pursued.

\section{Section V. Summary of Operable Unit Characteristics}

The Gunsite 720 Rubble Pit Unit was one of the anti-aircraft artillery gun emplacements the U.S. Army established at several locations near the perimeter of SRS. There is no documentation or record of any hazardous substance management or disposal at this unit. There is no evidence that any recent disposal activity has occurred. Also, there is no evidence of any burning or excavation at this waste unit.

\section{Media Assessment}

The RFI/RI Work Plan (WSRC, 1990) and RFI/RI Report (WSRC, 1996a) contain detailed information and analytical data for all the investigations conducted and samples taken in the media assessment of the Gunsite 720 Rubble Pit Unit. These documents are part of the Administrative Record File. The results of the RFI/RI, Report are summarized below.

In 1986, a magnetic survey was conducted to locate underground $\operatorname{tank}(\mathrm{s})$ believed to be buried at the unit. However, the results of the magnetometer survey were inconclusive.

In March 1988, four soil gas samples were analyzed for chlorinated hydrocarbons. No chlorinated hydrocarbons (chlorinated solvents) were detected.

In March 1989, a ground penetrating radar survey was also conducted. The survey indicated that there were no buried or underground objects in the area. Trenches were also excavated at the unit to visually characterize buried waste and to locate and identify any underground storage tanks that might be present (see Figure 2). No evidence of burial pits was found. All trenches were backfilled with the excavated materials and leveled. 


\section{Soils"}

During 1990,12 soil samples were obtained from various locations and depth intervals within the Gunsite 720 Rubble Pit Unit area and at one background location (see Figure 2). The concentrations detected for all the hazardous substances were below their respective EPA risk-based concentration levels.

In early 1993, SCDHEC expressed some concerns regarding the existence of the underground storage tanks at the unit and potential releases from the tanks and the drums that were located at the Gunsite 720 Rubble Pit Unit. SRS performed additional ground penetrating radar and magnetometer surveys, and also obtained additional soil samples from the areas where the drums had been found and the underground storage tank was believed to have been located. Samples were collected at various depths ranging from 1.2 meters (4 feet) down to 5.5 meters ( 18 feet). Figure 2 shows the locations of samples collected in the 1993 survey.

The ground penetrating radar and magnetometer surveys did not indicate the existence of an underground storage tank or any other buried debris. It was concluded that the tank had been removed.

No hazardous substances were detected in the underground storage tank area. In the drum area also, the maximum concentration of all the hazardous substances detected (except for chromium) were lower than the maximum concentrations found in the 1990 sampling. Hence, the only metal detected in 1993 sampling exceeding the 1990 maximum concentration was chromium. However, the concentration was significantly less than EPA risk-based concentrations for chromium $\left(\mathrm{Cr}^{+6}\right.$ and $\mathrm{Cr}^{+3}$ ).

Based on comparison of analytical results to risk-based concentrations and two times unit specific concentrations, it was evident that there had been no environmental impact due to hazardous substance disposal at or release from the Gunsite 720 Rubble Pit Unit.

\section{Groundwater}

Since preliminary investigations conducted in 1988 and soil samples collected in 1990 and 1993 concluded that there was no evidence of contamination, no groundwater investigations were conducted.

\section{Surface Water/Sediment}

No surface water or sediment sampling was conducted because the nearest surface water feature (the Upper Three Runs Creek) is located approximately 1.2 kilometers (3/4mile) from the Gunsite 720 Rubble Pit Unit.

\section{Section V1. Summary of Operable Unit Risks}

\section{Human Health Risks}

As part of the RCRA/CERCLA process for the Gunsite 720 Rubble Pit Unit, a risk assessment was performed using data generated during the assessment phase. Detailed information regarding the development of constituents of potential concern, fate and transport of contaminants and risk assessment can be found in the RFI/RI Report for the Gunsite 720 Rubble Pit Unit (631-16G) (U), WSRC-RP-95360, Rev. 1 (WSRC, 1996).

After combining analytical data and eliminating those analytes not detected in any samples, the data. were evaluated on the basis of quality with respect to sample quantitation limits, frequency of detection, relative toxic potential of the constituent, laboratory qualifiers and codes, and blanks. The remaining data (constituents detected) 
were compared to two times the unitspecific background and EPA developed

- Risk-Based Concentrations (RBCs).

RBCS developed by EPA Region III (EPA, 1995) were used to screen the constituents of potential . concern for the Gunsite 720 Rubble Pit Unit. This guidance provides reference doses and carcinogenic potency data for nearly 600 chemicals. These toxicity constants have been combined with "standard" exposure scenarios to calculate RBCS (i.e., chemical concentrations corresponding to fixed levels of risk; a hazard quotient of 1 , or a lifetime cancer risk of one in one million). The RBCS are very similar to preliminary remediation goals which are concentration goals for individual chemicals for a specific. medium and land use combinations at CERCLA Units.

Following the comparison to background and RBCs, it was concluded that the concentrations of all hazardous materials analyzed were below any EPA risk-based concentration action levels. Hence, there are no constituents of potential concern for . evaluation in a CERCLA baseline risk assessment (BRA), and there is no determinable risk associated with the Gunsite 720 Rubble Pit Unit.

\section{Current Land Use}

Since there is no current activity at the Gunsite 720 Rubble Pit Unit, the current land use scenario is not applicable.

\section{Future Land Use}

Since there is no constituents of concern and no determinable risk associated with the Gunsite 720 Rubble Pit Unit, the future land use scenario is not applicable.

\section{Ecological Risks}

Based on the physical and analytical data pertaining to this unit, there is no evidence that waste materials were managed or disposed of at the Gunsite 720 Rubble Pit Unit. Therefore, it is reasonable to conclude that this unit presents no significant ecological risk.

\section{Section VII. Description of the No Action Alternative}

Based on the unit characterization and risk assessment, the Gunsite 720 Rubble Pit Unit poses no risk to human health and the environment. Therefore, the unit requires no cleanup activities and the no action alternative is recommended for this unit. No additional alternatives were considered for evaluation.

The no action alternative means that no remedial action will be performed at the Gunsite 720 Rubble Pit Unit. There is no waste to treat, no institutional or engineering controls are required, and there are no applicable or relevant and appropriate requirements (ARARs). Because no further action would be taken, the Gunsite 720 Rubble Pit Unit would remain in its present condition. No costs will be involved for this action.

Since the Gunsite 720 Rubble Pit Unit poses no risk to human health or the environment and no action is warranted at this unit, the CERCLA Section 121 requirements are not applicable. The no action alternative will be the final action for the Gunsite 720 Rubble Pit Unit and there will be no five-year (ROD) reviews. This solution is meant to be permanent and effective in both the long and short term, and protective of human health and the environment. 


\section{Section VIII. References}

DOE (U. S. Department of Energy), 1994, Public Involvement, A Plan for the Savannah River Site, Savannah River Operations Office, Aiken, SC.

EPA (U.S. Environmental Protection Agency), 1995, Risk-Based Concentration Table, EPA-III, January -June 1995, dated March 7, 1995.

Federal Facility Agreement (FFA), 1993, Federal Facility Agreement for the Savannah River Site, Administrative Docket No. 89-05-FF, (Effective Date: August 16, 1993).

WSRC, 1990, RCRA Facility Investigation/Remedial Investigation Plan for the Gunsite 720 Rubble Pit Unit, WSRC-RP-90-1049, Westinghouse Savannah River Company, Aiken, SC.

WSRC, 1996a, RCRA Facility Investigation/Remedial Investigation Report for the Gunsite 720 Rubble Pit Unit (63116G) (U), WSRC-RP-95-360, Rev. 1, Westinghouse Savannah River Company, Aiken, SC.

WSRC, 1996b, Statement of BasisY.Proposed Plan for the Gunsite 720 Rubble Pit Unit (631 -16G) (U), WSRCRP-96-217, Rev. 1, Westinghouse Savannah River Company, Aiken, SC. 